\title{
GRADUATES' PERCEPTION OF TOURISM AND HOSPITALITY DEGREE PROGRAM RELEVANCE TO CAREER ATTAINMENT: A CASE OF GRADUATES FROM THREE STATE UNIVERSITIES IN ZIMBABWE
}

\author{
Musawenkosi M. Tapfuma ${ }^{1}$, Oliver Chikuta ${ }^{2}$, Felicity N. Ncube ${ }^{3}$, Rudorwashe Baipai ${ }^{4}$, \\ Precious Mazhande ${ }^{5}$, Vitalis Basera ${ }^{6 *}$ \\ ${ }^{1,3,5}$ Department of Tourism and Hospitality Management, Midlands State University, Gweru, Zimbabwe \\ ${ }^{2}$ Faculty of Hospitality and Sustainable Tourism, BOTHO University, Botswana \\ 4,6 Department of Tourism and Hospitality Management, Manicaland State University of Applied Sciences \\ (MSUAS), Mutare, Zimbabwe
}

Correspondences author's email: vitalisbasera@yahoo.com

\begin{abstract}
The process of making career choices is complex since there are diverse factors affecting students' selection of programs when they enrol in higher and tertiary institutions. Just like in any other discipline, tourism and hospitality management graduates are affected by various factors when deciding their careers post-graduation. Preliminary studies have shown that a significant percentage of tourism and hospitality graduates divert from tourism to some other, sometimes totally unrelated, industries for employment. This study seeks to discover tourism and hospitality degree graduates' perceptions and career attainment in Zimbabwe. The following critical questions were asked in order to achieve the objective of the study; Why do they enrol for the tourism/hospitality program in the first place, that is what factors affect the students' selection process of tertiary education programs? and why do some end up in totally different fields after graduating? Qualitative research approach was adopted in order to understand the graduates' perceptions, data was collected by the way of interviews. Data was analysed using the thematic approach. Findings revealed that while most of the graduates are employed in the tourism and hospitality industry in Zimbabwe, they are not satisfied with their jobs. Some feel that they studied tourism/hospitality as a last resort hence they do not have satisfaction while others are only in the industry because they do not have an option. Poor working conditions and poor remuneration
\end{abstract}


were also cited as causes of dissatisfaction. There are however a significant number who do not regret their career choice.

Key words: Perceptions; Tourism and Hospitality Management; Graduates; Career; Satisfaction

\section{INTRODUCTION}

The tourism and travel industry is among the world's biggest industries, driving socioeconomic development and employment creation (WTTC, 2020). The industry is key in driving prosperity, empowering youth, women, and other groups of society. Travel, hospitality and tourism benefits are far beyond its impacts of employment and GDP as there are also induced impacts to other sectors along the value chain (UNWTO, 2018). Globally, the tourism industry ranked third in 2018 ahead of automotive industry and after fuels and chemicals industry and in several developing nations, tourism is the highest export contributor (UNWTO, 2018). In 2018, travel and tourism industry contributed around 10,3\% of the world's GDP, 1 in every 10 jobs and 1 in every 4 of all net new jobs created over the last five years (WTTC, 2020). In Africa travel and tourism contributed 2.2\% to GDP and employing 24.6 million people in 2019 (WTTC, 2020) while in Zimbabwe tourism industry in 2019 contributed 10\% to GDP, 7.2\% contribution to exports and 5.2\% (+90 000 jobs) contribution to employment (ZTA, 2019).

The hospitality and tourism industry in Zimbabwe, is one of the substantial earners of revenue in overall and foreign exchange in particular. With respect to total worldwide investments, about $9 \%$ are in hospitality and tourism industry. The strength of any industry is determined by its human capital and this is especially true with the tourism and hospitality industry given its dependence on human interface. In this regard, tourism graduates from institutions of higher learning are a vital resource that can improve the tourism industry competitiveness. Training and development of competent human resources in the tourism industry is one of the strategies considered to improve competitive position of Zimbabwe's tourism and travel industry (Shereni, 2019). 
In Zimbabwe universities and colleges are producers of workforce for the tourism industry. Colleges, Technical Vocational Education and Training provide manpower with operational skills while universities provide human capital with managerial skills, technological competencies, and critical thinking. The universities normally enrol students with five Ordinary level passes with English Language and Mathematics and at least two Advanced level passes. Technical Vocational Education and Training colleges require candidates with five ordinary level passes for a diploma qualification and basic literacy for certificates. At least 150 candidates graduate with degrees in tourism and hospitality management annually (MSU, 2018; UZ, 2018; Giang \& Mohammad, 2014; CUT, 2019) and 300 with certificates and diplomas from vocational training colleges and polytechnic colleges (HEXCO, 2018). The graduates compete for available positions in the developing industry with low demand for expert labour and slow expansion (Mehta et al., 2013).

Tourism and hospitality graduates are just like any other graduates and their career choices upon graduation is affected by many factors. Preliminary indications are that the graduates divert from tourism industry to unrelated industries for employment (De Castro, 2017; Lusby, 2017). Hence this study qualitatively explored the university tourism and hospitality graduates' perceptions of job match after completing their program. The study sought to find out if the attainment of tourism and hospitality degree had value to their careers and why? Previous research has proven that some graduates perceived attainment of degrees provided them with career advancements and opportunities (Conrey, et al., 2020). A qualitative research approach was adopted so as to understand the feelings and perceptions of graduates as they brought novel ideas and views on the phenomenon being studied. Since the primary data collected through interviews was non-numerical, it made qualitative research approach relevant to this study by providing factual and descriptive information (Creswell, 2014). The authors further explains that the relationship between the researcher and the participants in a qualitative approach makes the understanding of a phenomenon better since there is human behaviour involvement which include thoughts, interaction and reasoning. The researchers were able probe further so as to get rich data from the participants through 
qualitative data collection methods, thus interviews. Qualitative research approach allowed the researchers to thematically analyse data by deducing meaning from the participants' voices. Therefore, understanding graduates' perceptions will enlighten both education institutions on student motivation for enrolling, and assist prospective students on career decision making. This study traces three groups of tourism and hospitality degree graduates from three state universities in Zimbabwe. Tourism and hospitality industry is a key pillar in the development of the country, so appreciating the perceptions of tourism and hospitality graduates will improve manpower planning in the country.

\section{Tracer Study}

A tracer study, also referred to as graduate survey, is a standardised survey (in written or oral form) of graduates from education institutions, which takes place sometime after graduation or at the end of the training (Schomburg, 2016). The focus of a tracer study can be multiple, but regular issues include questions on study advancement, the passage to work, job career, current occupation, use of learned competencies and ties to the education institution. This tracer study is inclined on tourism and hospitality graduate's education-job career(mis)match, revisiting the motivation for their enrolment in the tourism and hospitality degree program. Tracer studies afford an avenue to analysing university graduates in relation to the labour market (Ssembatya \& Ngob, 2015). Tracer studies offer information concerning employability of graduates and the type of employment they gain; a match or mismatch between educational qualifications and the essential work skills and gaps of an educational program which assist in positioning the university training to the needs of the economy (Schomburg, 2008).

\section{Tourism and Hospitality industry and Human Capital Development}

Tourism and hospitality is a fast growing industry today world over and it incorporate above fifteen related businesses which include lodging, transportation, food service and tour operators (De Castro, 2017). The tourism industry is an amalgamation of institutions, 
supporting human resources, financing instruments, information systems and organizational structures that connect institutions and resources that cater for the needs of both foreign and domestic travelers (Buama, 2018). Supporting human resources include hotels and restaurant managers, housekeeping and front office supervisors, waiters, chefs, bartenders and other related professional workers directly involved in tourism and hospitality services. Universities are part of the higher and tertiary education system which is an important building block for human capital development (Buama, 2018). Tertiary education systems respond to national goals national in most nations world over; first, to educate the youth to become productive active members of society. Secondly it pursues to meet industry demand for a skilled and globally competitive labor force. Thirdly it offers ongoing effort to reach international education standards through increasing the quality of human capital and productivity regarding national and economic development (Buama, 2018; Muzuzu University , 2018). The tourism and hospitality management graduates can pursue careers in academia, in entrepreneurship as tour operators, travel agents, event managers and in institutional catering. Other opportunities are in management posts in safaris, parks and wildlife and the hotel industry (UZ, 2020).

\section{Career Perceptions and Expectation of Hospitality and Tourism Graduates}

Hospitality and tourism graduates' attitudes regarding being employed in the hospitality and tourism industry are expected to be predisposed by their training experiences mostly practicum and work-related learning (De Castro, 2017). Graduates' inspiration and commitment to a hospitality or tourism career differs and is extremely hooked on their industry internship experiences, university enrolment, social status, working hours, and core competencies (De Castro, 2017; Buama, 2018; Celis et al., 2013; Muzuzu University , 2018; Ssembatya \& Ngob, 2015; Xiao, 2012; Wang \& Tsai, 2014; Lu \& Adler, 2009; Lusby, 2017). Previous tracer studies of tourism and hospitality graduates have been analysed one after another so as to thread common career perception of tourism and hospitality from literature. 
The analysis reviewed the students motivation for studying hospitality, their career prospects and why they end up in other industries after graduation.

Bauma (2018) did a study to evaluate and trace the employability of graduates of Bachelor of Science in Tourism graduating class of 2012 using a validated modified tracer questionaire at Laguna StatePolytechnic University Los Banos Campus. The study findings revealed reasons behind the graduates dificulty in finding a job as lack of work experience, no personal links/strong refferals, economic recession and few jobs with strong competition. The working graduates were $57 \%$ and majority worked in government with majority occupying rank and file level.

Celis et al. (2013) did a tracer study to determine employability of the graduates of Hotel and Restaurant Management of Lyceum of Philippines from 2005- 2009 using a descriptive design. The results showed that the graduates are gainfully employed within the country but on contractual basis and got a job in less than two years after graduation. The graduates landed the jobs based on human relations skills, communication skills and languages they learned. Determination was the main work philosophy for the graduates, benefits and salaries were a big part in influencing leaving or staying at the initial job.

Muzuzu University (2018), the Mzuzu University (MZUNI) faculty of tourism, hospitality and management in 2018 conducted a tracer study to understand challenges that its graduates face in the job market using a census of 2016 graduates and administering questionnaires. Some of the graduates reported they acquired jobs while at university, yet others showed low levels of fulfilment with the degree they studied highlighting that they attained better competencies in management courses than in operational courses. The results indicated that majority of the graduates are working in either non-tourism and tourism organisations in private and public sector nonetheless some were yet to get jobs. A good number of graduates got jobs within twelve months after graduation, exclusively via social capital and a few with the assistance of faculty's staff. Most of the graduates are employed in cites. Graduates employed in tourism industry were found to be receiving decent salaries and benefits than those in non-tourism sectors but voiced low satisfaction with their occupations. 
De Castro (2017) conducted a study to ascertain the employability of the graduates of Bachelor of Science in Hotel and Restaurant Management of one State college in the Philippines. The research ascertained that most of graduates were employed in the country and a small number outside the country due to lack of English qualifications requirements. Majority attained their first work in within three months in hotels and fast foods, ironically other graduates still had a struggle to find a job because of few job vacancies. The results showed that most of the graduates have their jobs relevant to their qualifications. The graduates reported that all the skills they learnt are relevant and useful to their present employment.

Pang (2010)'s tracer study of hospitality students from the Polytechnic in Singapore revealed that students were not keen to join the hospitality industry due to the strenuous and stressful nature of jobs, shift work, extended working hours, dealing with irregular situations in the work setting, low starting salary as compared to other industries. The semi-professional description of the hospitality and tourism industry was also cited as a cause for dissatisfaction. Also, students with parents from Asian-Singapore context do not get support from the parents to study tourism and hospitality as jobs in the industry are seen as "servitude" and have low chances of elevation from file and rank.

Lusby (2017) studied the perceptions and attitudes of Chinese students in Macau and American students learning at a public university in the USA using one-way variance analysis. Results exposed substantial variances among the two groups. In general, American students showed more positive feelings towards a career in tourism, prospects for promotions and salary. The Chinese students proved more negative feelings towards a career in tourism due to long working hours, low salary and low benefits.

Ssembatya \& Ngob (2015) conducted a tracer study at Makerere University of 2012 graduates and noted that tallying of graduates with jobs is vital in reducing the graduate unemployment by strengthening internship programs. The graduates from the university acquired jobs through advertisements. Most of the graduates failed to further education due to lack of funds and very few started their own enterprises. 
Wang \& Tsai (2014) investigated the perceptions of senior hospitality students and industry managers on employability in the Taiwan hospitality industry using questionnaires. The results were intended to help students studying hospitality management to plan for their career according to the requirements of the hospitality industry. The results exhibited that; from the perceptions of mangers and senior students, the graduates lack confidence in their employability, mainly in areas of professional management skills.

Giang \& Mohammad (2014)'s tracer study of international students in Finland showed that students generally embrace optimistic prospects about employment after graduation, with decent working condition, high salary and working in their specialised field. Nevertheless, their expectations of getting job easily are not high, and their biggest obstacle in entering hospitality and tourism industries in Finland is their poor Finish language competences. Lack of language skills, experiences, recommendations and intense job competition are also challenges encountered entering the industry.

Tourism and hospitality graduates expect to pursue a profession in the tourism and hospitality industry with a wish for a postgraduate degree (Lu \& Adler, 2009).Topics taught in tourism and hospitality degree that seem to be useful to the students in their career include marketing, business management, food preparation, tourism psychology, economics, industrial practices, human resources, international languages, services delivery, and communication skills (Brown et al., 2008; Chimutingiza et al., 2012; De Castro, 2017).

\section{Influence of Personal Development in the Tourism and Hospitality Workplace}

Learned human relations skills, communication skills, work experience helped graduates to land jobs within shortest possible time after graduation (Celis et al., 2013). Studies also show that opportunities for personal development, high salaries, international exposure, low university entry points to be among most reasons that leads students to pursue studies in studies in Tourism and hospitality management and get employed in the industry (Lu \& Adler, 2009; Giang \& Mohammad, 2014). Students highlighted lack of promotion opportunities to higher positions in the tourism and hospitality industry as the main cause why 
they did not want to go in the industry (Lu \& Adler, 2009). Tourism graduates also cited long working hours, low pay and low benefits, tough jobs, poor working conditions and low social status, 'servitude' nature of the jobs, little prospects of promotion and stiff competition in the labor market as other reasons for not being employed in the hospitality and tourism industry (Lusby, 2017; Xiao, 2012; Pang, 2010).

Hospitality and tourism graduates in developing countries and Asian nations have negative career expectations in the hospitality industry with most of the graduates working in government institutions (Buama, 2018; Muzuzu University , 2018; De Castro, 2017; Pang, 2010) while in America the graduates have very positive perceptions and expectations (Lusby, 2017). According to Marchante et al. (2007) better working experience substitute education for tenure, promotion and on the job training in hospitality industry, therefore workers can compensate for their lack of education. Graduates in tourism and hospitality management present their academic degree in the labour market in a number of ways; for jobs in tourism and hospitality they present themselves as graduates of hospitality management, for jobs in business management and administration they present themselves as management graduates and for casual job offers, they present themselves as management students majoring in tourism management (Poria \& Reichel, 2019). The varied degree presentation seems to answer public insights that hotel management does not need academic education and the academic aptitudes of those studying it is questionable based on equity theory, social signaling theory, impression management, academic status philosophy of etymological and the concept of embarrassment (Marchante et al., 2007; Poria \& Reichel, 2019). A stronger three-way connection between stakeholders (employers, graduates and educationist) is important for optimistic perceptions and expectations of graduates' careers through continual process of revitalization and modification of tourism and hospitality curriculum to produce holistic competent graduates for the industry (Chimutingiza et al., 2012).

Success of an academic institution is due to the employability of its graduates (Celis et al., 2013). The quality of graduates is very much a function of quality facilities and instruction because these will help make sure that graduates are prepared with knowledge, skills, 
competencies and morals that empower them to work in their specialised field. Preliminary research shows that there is no published work to trace tourism and hospitality graduates in Zimbabwe. This study sought to find the perceptions of tourism and hospitality graduates on the qualification-job match or lack thereof.

\section{RESEARCH METHODOLOGY}

The study adopted a phenomenological philosophy and used a qualitative research approach to collect and analyse data. As drawn from the original work of Heidegger (1988) cited in Gill (2020) phenomenological philosophy is an interpretative research approach that explores the human experience in the environment that they live in. Since this study explored the perceptions of participants, a phenomenological approach was chosen so as to seek the essences of experiences of graduates after completing the tourism and hospitality program as explained by Gill (2020). The one methodology adopted in the study; thus, the qualitative research method justified the adoption of a phenomenological philosophy as the researchers were studying the nature of a phenomenon so as to understand why things are happening in that way. Since experiences, views, and perceptions cannot be measured, a qualitative research approach provides a better method of data analysis and presentation of such Busetto et al. (2020). Hence this study explored perceptions of tourism and hospitality graduates on academic-career match and why they hold such perceptions. An exploratory research design was adopted as to understand the phenomenon from the participants' view since ideas can be novel.

In a classical study conducted by Saunders (1982) cited in Gill (2020) argued that in a phenomenological study, a few numbers of participants should be used so as to probe further the participants to get more information through in-depth interviews. A sample of thirty (30) tourism and hospitality degree graduates from three state universities in Zimbabwe were selected conveniently. Data saturation method was used to arrive at the thirty (30) respondents. Ritchie et al. (2003) stipulated that qualitative samples are usually fewer than fifty. These participants graduated between the period of 2013 and 2016 . 
Thus, this study used in-depth interviews to collect data from graduates from Midlands State University, University of Zimbabwe, Chinhoyi University of Technology. Online and telephonic interviews were used to collect data from the graduates upon obtaining their contacts from the researchers' contact since the researchers were lectures in some of those universities. More contacts were availed through referrals by some participants. By conducting such interviews, the researchers managed to identify themes from the participants' voices where data was analysed and meaning was derived from the experiences. Notes and recordings were taken during the interviews, which were later transcribed and grouped into themes.

\section{RESULTS AND DISCUSSION}

This section presents and discusses the findings of the study.

\section{Degree of Qualification-Job Mismatch}

A total of 30 interviews were conducted successfully. The findings are as presented in table 1.1 in terms of the degree of qualification-job mismatch.

Table 1.1. The Degree of Qualification-Job Mismatch

\begin{tabular}{|c|c|c|}
\hline $\begin{array}{c}\text { Employed in a Tourism and Hospitality Related } \\
\text { field }\end{array}$ & Employed in a non-related field & Un employed \\
\hline 28 & 1 & 1 \\
\hline
\end{tabular}

28 of the respondents are employed in tourism and hospitality related sectors, while 1 is employed in a non-tourism and hospitality related field and another 1 being unemployed. The findings show that more tourism and hospitality graduates are employed in fields that are aligned with their degree qualifications, with exception of just a small fraction being either employed in non-related sectors or unemployed. The findings are in line with conclusions drawn from a study by the Mzuzu University (MZUNI) faculty of tourism, hospitality, and management in 2018.

The results indicated that most graduates are employed in both public and private sector in tourism and non-tourism organization, but some are yet to find jobs. The results by De 
Castro (2017) in a study to determine the employability of the graduates of Bachelor of Science in Hotel and Restaurant Management of one State college in the Philippines also indicated that most of the graduates have their jobs relevant to their qualifications but earn low salaries.

\section{Factors that Lead to the Pursuit of the Tourism and Hospitality Degree Program}

The second objective was to determine the factors that lead to the pursuit of the Tourism and Hospitality degree. The respondents were asked "Why did you enroll for the Tourism and Hospitality program?" and "What factors affected your selection process for choice of tertiary education programs"?

From the findings it was stablished that for 18 of the respondents the tourism and hospitality degree program was their first choice while for 12 the program was not their first choice. One of the respondents said:

"I did not choose the program, actually it was my last choice. Imagine the shock I got when the university actually accepted me for Tourism and Hospitality Management instead of my first or second choice program".

While another said: "I applied for the Tourism and Hospitality degree as a means of trying to bridge my way to the program that I wanted to pursue".

The following themes emerged as the factors that affected selection process for choice of tertiary programs.

\section{Conceptions Held about the Industry}

The findings show that 18 the respondents leaned towards the tourism and hospitality degree program due to the conceptions they had about the industry. Some of the responses from the respondents were:

"The main reason I chose the program is because I thought it was something out of this world. I thought I would travel and see the world". 
Another said: "I love travelling and nature and I thought this is what the industry was all about. I believed by acquiring more knowledge about the industry would help me in terms of employability".

\section{Entry Requirements}

13 of the respondents highlighted that it was because of issues related to entry requirements that contributed to the pursuit of the tourism and hospitality program. One of the respondents said:

"With the subjects and points I got at 'A' level, I best qualified for enrolment for the tourism and hospitality degree program".

Another said: "That's what I qualified for with the subjects I did at 'A' level". Another said: "I did not have Mathematics at O level and for most of the commercial degree programs besides tourism and hospitality management, O level maths was a prerequisite".

\section{Availability of Places}

12 of the respondents stated that availability of enrolment space for their program of choice led to the pursuit of the tourism and hospitality degree. One of the respondents said: "I had applied for accounting as my first choice but was told that the program no longer had space for enrolment. Hence I ended up settling for tourism and hospitality management".

Another respondent said: "The only reason I took the program is because I applied late for enrolment and the institution then suggested I enrol or another program as the one I wanted to enrol for was full".

Although some of the respondents attributed their programme choice to singular factors, some of them stated that it was a blend of several factors that pushed their choice, the findings on factors that lead to the pursuit if a tourism and hospitality degree are in line with findings by Giang \& Mohammad (2014) study of employment opportunities and expectations of international tourism and hospitality graduates in Finland. 


\section{Factors that Influenced Job Choice}

On the factors that influenced job choice the result revealed that 28 of the tourism and hospitality graduates' job choices were influenced by the qualifications they possessed, however their current positions in the various organisations they are in were mainly influenced by the high levels of unemployment in the market. The graduates were anticipating managerial positions. One of the respondents had this to say:

"When I graduated it was very hard to get a job and when I finally did it was a lowlevel position, but I had had enough of staying at home, so I took the job".

One of the graduates attributed their job choice to difficulty in getting employment in the tourism and hospitality sector, which is why they ended up settling for employment in nonrelated sectors while one of the respondents has completed failed to get employment in the tourism related sector due to the same reason. The results clearly indicated that the biggest fraction of tourism and hospitality graduate's job choice is highly influenced by their academic qualification this is in line with findings by Celis et al. (2013) when they investigated the employability of graduates of Bachelor of Science in Hotel and Restaurant Management.

\section{Job Satisfaction}

Findings reveal that of the 30 respondents 19 of the graduates are no satisfied with their current jobs. This fraction is made up of graduates employed in the tourism and hospitality related sector. They attributed this to several issues including lack room for growth within their respective companies, working conditions and salaries. One of the respondents said:

"No, I cannot say I am satisfied with my job because I was longing for a managerial job in big institutions like five-star hotel or the airline sector but now I am at a twostar guest house. I feel like I am not doing much considering my qualifications. I have not gained much in terms of on-the-job experience". 
Nine who are employed in tourism and hospitality related sectors are satisfied with their jobs. These respondents are either employed in the academic field of the industry or ventured into tourism and hospitality related entrepreneurial activities. They attribute their satisfaction mainly to the flexibility of working hours and salaries.

One of the respondents also said they are satisfied with their current jobs even though they were not employed in sectors related to their degree qualifications. This is what they had to say:

"I love my current job even though it is not related to what I studied. I get to set my own workload and peg my own salary."

The findings show that even though most of the tourism and hospitality graduates are employed in their related sector they are not satisfied with their jobs the findings are in line with those of Muzuzu University (2018) which concluded that even though graduates employed in tourism industry were found to be receiving decent salaries they indicated low satisfaction with their occupations which was also observed in a related study by Pang (2010). 19 students reported to be unsatisfied with their jobs and this may corelate with the reason why they even enrolled for the program. Most of them enrol due to misconceptions they held about the industry which in fact did not come to be. The results indicated that the graduates hold positive perceptions of the tourism and hospitality degree relevance to career attainment since the majority are employed despite job challenges.

\section{CONCLUSION}

In Zimbabwe the majority of the tourism and hospitality graduates are employed and they hold positive perception of the tourism and hospitality degree program despite circumstances that led them to study the degree and work place challenges. From the findings, it can be concluded that a significant percentage of Tourism and Hospitality Management graduates were forced by circumstances beyond their control to enrol for the degree. Most of them had either not qualified for the program of choice or had found the placed already full 
and the only option available was tourism and or hospitality management. Most are employed in the hospitality and tourism industry despite that fact that some of them are not satisfied with their jobs. It can also be concluded that the reasons for job dissatisfaction are varied but the outstanding ones are (i) lack room for growth within their respective companies, (ii) poor working conditions and (iii) poor salaries. The implications of the findings are that prospective students should do enough research before they select a program of study. This will help them make informed decision which will make them happy at university and work. Training institutions also need to give enough information to the prospective students in order to help them make informed decisions. Furthermore, the universities have a task to build confidence in the students to dispel any negative cognitive dissonance that comes with making such life choices. Innovative teaching and learning as well as adequate facilities on and off campus may turn infidels into stalwarts for the tourism or hospitality programs. Tourism and hospitality employers need to improve on job satisfaction issues.

It is important to note that this study was qualitative in nature and only managed to involve thirty out of the many students who graduated in the period in question. While the results of this study give significant insights into graduate perception, the findings may be difficult generalise for all students who graduated from state universities in Zimbabwe. In future there is need to carry out a quantitative study involving a bigger number of students and also a comparative study with graduates from other degree programs can give an insightful result depicting graduates career attainment at national level.

\section{REFERENCES}

Adams, L. (2015). A Review of Hospitality and Tourism Management Graduates' Post Education Employment. Appalachian: Appalachian State University.

Brown, E. A. (2011). Hospitality management graduates' perceptions of career factor importance and career factor experience and the relation with turnover intentions. Graduate Theses and Dissertations. Capstone: IOWA State University.

Brown, P., Hesketh, A., \& Williams, S. (2008). Employability in a Knowledge driven Economy. Journal of Education and Work, 2:16.

Buama, C. A. (2018). Tracer and Employability Study: BS Tourism Graduates of Laguna State Polytechnic University Los Banos Campus. 4th International Research Conference on Higher Education (pp. 243-253). KnE Social Sciences. 
Busetto, L., Wick, W., \& Gumbinger, C. (2020). How to use and assess qualitative research methods. Neurological Research and Practice, 2(4), 1-10.

Celis, M. C., Festijo, B., \& Cuetto, A. (2013). Graduate's employability: A tracer study for Bachelor of Science in Hotel and Restaurant Management. A Peer Reviewed International Journal of Asian Academic Research Associates, 1:11.

Chimutingiza, F., Mwando, M., \& Kazembe, C. (2012). The hospitality and tourism honours degree programme: Stakeholders' perceptions on competencies developed. Journal of Hospitality Management and Tourism, 3(1): 12-22.

Conrey, M. L., Roberts, G. J., Fadler, M. R., Garza, M. M., Johnson, C. V., \& Rasmussen, M. (2020). Perceptions after completing the degree: A qualitative case study of select higher education doctoral graduates. International Journal of Doctoral Studies, 15, 305-327. doi:10.28945/4572

Creswell, J. W. (2014). Research Design: Qualitative, Quantitative and Mixed Methods Approaches (4th ed.). Thousand Oaks, CA: Sage.

CUT. (2019). Bsc in Tourism and Hospitality Graduates. Chinhoyi: Chinhoyi University of Technology.

De Castro, G. L. (2017). Tracer Study of Hotel and Restaurant Management Graduates of One State College in the Philippines from 2014-2016. Asia Pacific Journal of Education, Arts and Sciences, 4:1, 41-47.

ETF-Cedefop-ILO. (2016, JUNE 25). Carrying out tracer studies - Guide to anticipating and matching skills and jobs Vol. 6. Retrieved from www.etf.europa.eu/web.nst/pages/Vol._6_Tracer_studies.

Giang, L. L., \& Mohammad, N. (2014). Employment for International Students after Graduation from Universities of Applied Sciences in Tourism and Hospitality Degree Programmes in Finland: Expectations and Obstacles. Saimaa : Saimaa University of Applied Sciences.

Gill, M. (.-M. (2020). Qualitative Analysis: Eight approaches. London: Sage.

HEXCO. (2018). Higher Education Examinations Report. Higher Education Examinations Council.

Le, A. H., Klieve, H., \& McDonald, C. V. (2018). Tertiary students' perceptions of hospitality careers in Vietnam. Empirical Research in Vocational Education and Training, 10:14.

Lu, T. Y., \& Adler, H. (2009). Career Goals and Expectations of Hospitality and Tourism Students in China . Journal of Teaching in Travel \& Tourism, 9:1-2, 63-80,.

Lusby, C. (2017). American and Macau student perceptions towards working in the tourism and hospitality industry. International Interdisciplinary Business-Economics Advancement Journal,, 2(1), 54-64.

Marchante, A. J., Ortega, B., \& Pagán, P. (2007). An Analysis of Educational Mismatch and Labor Mobility in the Hospitality Industry. Journal of Hospitality \& Tourism Research, 31:299.

Mehta, A., Felipe, J., Quising, P., \& Camingue, S. (2013). SWhere have all the educated workers gone? Services and wage inequality in three Asian economies. Metroeconomica, 64(3):466-497.

MSU. (2018). Bachelor of Tourism and Hospitality Management Graduates. Gweru: MSU.

Muzuzu University . (2018). Faculty of Tourism, Hospitality and Management Graduate Tracer Study. Muzuzu University.

Pang, J. M. (2010). Perceptions of the tourism and hospitality industry by Singapore polytechnic hospitality students: An exploratory study. Thesis(2010). Las Vegas: University of Nevada.

Poria, Y., \& Reichel, A. (2019). How Do Hotel and Tourism Management Students and Graduates Present Their Academic Degree? . Journal of Hospitality \& Tourism Education.

Ritchie, J., Lewis, J., \& Elam, G. (2003). Designing and selecting samples. In J. Ritchie, \& J. Lewis, Qualitative research practice. A guide for social science students and researchers (pp. 77-108). Thousand Oaks, CA: Sage.

Schoffstall, D. G. (2013). The benefits and challenges hospitality management students experience by working in conjunction with completing their studies. Thesis. Capestone: IOWA State University. 
Schomburg, H. (2008). Handbook for graduate tracer studies, Centre for Research on Higher Education and work. University of Kassel.

Schomburg, H. (2016). Carrying out tracer studies: Guide to anticipating and matching skills and jobs. European Training Educating, V.6.

Shereni, N. C. (2019). The role of technical and vocational training (TVET) in restoring hospitality sector specific skills in Zimbabwe: A student perspective. Journal of Hospitality and Tourism Education.

Ssembatya, V. A., \& Ngob, R. K. (2015). Makerere University Tracer Study of 2012 Graduates. Makere University.

Ungui, C. R., Asilo, A. M., Asilo, N. R., Mira, S. B., \& Ylagan, A. P. (2014). Employability of Tourism Graduates in an Autonomous University for School Year 2011-2012. Scholars Journal of Economics, Business and Management, 1(5):186-196.

UNWTO. (2018). UNWTO Tourism Highlights. Spain: UNWTO.

UZ. (2018). Bsc in Tourism and Hospitality Graduates. Harare: University of Zimbabwe.

UZ. (2020, 07 1). University of Zimbabwe. Retrieved from www.uz.ac.zw/home/commere/tourism: www.uz.ac.zw

Wakelin-Theron, N., Ukpere, W. I., \& Spowart, J. (2018). Perception of tourism graduates and the tourism industry on the important knowledge and skills required in the tourism industry . African Journal of Hospitality, Tourism and Leisure, 7(4).

Wang, Y., \& Tsai, C. S. (2014). Employability of Hospitality Graduates: Student and Industry Perspectives. Journal of Hospitality and Tourism Education, 26(3): 125-135.

WEF. (2018). Global Tourism Competitive Report. World Economic Forum.

WTTC. (2020). Travel and Tourism: Global Economic Impact. World Travel and Tourism Council.

Xiao, X. (2012). Career Behaviours of Tourism Management Students in China. Thesis . Kent: Kent State University.

ZTA. (2019). Tourism Trends and Statistics Report. Harare: Zimbabwe Tourism Authority. 